Special issue / Número especial

\title{
Mineral deposits of Latin America and the Caribbean. Preface
}

\author{
Depósitos minerales de América Latina y el Caribe. Prefacio
}

Joaquín A. Proenza ${ }^{1, *}$, Lisard Torró ${ }^{2}$, Carl E. Nelson ${ }^{3}$

\begin{abstract}
Departament de Mineralogia, Petrologia i Geologia Aplicada. Facultat de Ciències de la Terra,Universitat de Barcelona. C/ Martí i Franquès, s/n, 08028, Barcelona, Spain.

${ }^{2}$ Geological Engineering Program, Faculty of Sciences and Engineering, Pontifical Catholic University of Peru (PUCP), Av. Universitaria 1801, San Miguel, 15088, Lima, Peru.

${ }^{3}$ Recursos del Caribe, S.A., $236023^{\text {rd }}$ Street, Boulder, 80304, Colorado, United States.

* Corresponding author: (J.A. Proenza) japroenza@ub.edu
\end{abstract}

\section{PREFACE}

The region that encompasses Latin America and the Caribbean is a preferential destination for mining and mineral exploration, according to the Mineral Commodity Summaries 2020 of the US Geological Survey (https://www. usgs.gov/centers/nmic/). The region contains important resources of copper, gold, silver, nickel, cobalt, iron, niobium, aluminum, zinc, lead, tin, lithium, chromium, and other metals. For example, Chile is the world's largest copper producer and the second largest lithium producer. Brazil is the world's leading niobium producer, the second largest producer of iron ore, and the thirdranked producer of tantalum. Cuba contains some of the largest reserves of nickel and cobalt in the world, associated with lateritic Ni-Co deposits. Mexico is traditionally the largest silver producer and contains the two largest mines in this commodity and, along with Peru, Chile, Bolivia and Argentina, accounts for more than half of the total amount of global silver production. The region also hosts several world-class gold mines (e.g., Pueblo Viejo in the Dominican Republic, Paracotu in Brazil, Veladero in Argentina, and Yanacocha in Peru). Also, Bolivia and Brazil are among the world's leading producers of tin.

The region hosts a variety of deposit types, among which the most outstanding are porphyry copper and epithermal precious metal, bauxite and lateritic nickel, lateritic iron ore from banded iron-formation, iron-oxide-copper-gold (IOCG), sulfide skarn, volcanogenic massive sulfide (VMS), Mississippi Valley type (MVT), primary and weathering-related Nb-bearing minerals associated with alkaline-carbonatite complexes, tin-antimony polymetallic veins, and ophiolitic chromite.

This special issue on Mineral Deposits of Latin America and the Caribbean in the Boletín de la Sociedad Geológica Mexicana contains nineteen papers. Contributions describe mineral deposits from Mexico, Panama, Cuba, Dominican Republic, Colombia, Venezuela, Ecuador, Chile, and Argentina. This volume of papers covers four mineral systems (mafic-ultramafic orthomagmatic mineral systems, porphyry-skarn-epithermal mineral systems, iron oxide copper-gold mineral systems, and surficial mineral systems). This special issue also includes papers on industrial minerals, techniques for ore discovery (predictive modelling of mineral exploration using GIS), regional metallogeny and mining history. The articles contained in this volume are briefly outlined below.

Mafic-ultramafic orthomagmatic mineral systems $\left(\mathrm{Fe}_{\mathrm{C}} \mathrm{Ti}\right.$-V oxide deposit, chromitite and $C r-P G E)$

The paper by Betancur et al. presents the first detailed mineralogical data on Fe-Ti-(V) oxide mineralization of the Don Dieguito massif-type anorthosite 
suite, Sierra Nevada de Santa Marta, Colombia. The authors cite textural and mineralogical support for an origin by fractional crystallization and magma mixing. The mineral assemblages and textures observed are similar to those of other major ilmenite deposits worldwide.

The paper by Colás et al. provides a petrographic and geochemical characterization of metamorphosed chromitite bodies hosted in serpentinized peridotite from the Eastern Pampean Ranges in northern Argentina. Complex textures and geochemical fingerprints allow the authors to identify three types of chromitites that crystallized during retrograde and subsequent prograde metamorphism to granulite facies conditions. The proposed sequence of metamorphic events agrees with that of suprasubduction zone ophiolitic chromitites that were metamorphosed during continent-continent collisional orogeny.

The paper by Hernández et al. describes chromitites and associated metaperidotites from the Medellin Metaharzburgitic Unit located in the Central Cordillera of Colombia. The authors present new REE, LILE and HFSE data in support of a supra-subduction zone (back-arc basin/incipient arc scenario) setting in which the chromitites crystallized from tholeiitic magma. They concluded that compositional variations of the accessory chromian spinel could be related to superimposed medium-T metamorphism that reached amphibolite facies.

The paper by Mendi et al. addresses the petrogenesis of a chromitite body from the Cerro Colorado ophiolite located in the Paraguaná Peninsula in the Venezuelan Caribbean. Low-Cr content and trace element distribution in chromitites from this locality concur with those of chromitites from Mesozoic ophiolites in the shallower portions of the Moho Transition Zone. Back-arc basin basalts are the most probable melts in equilibrium with chromitites in Cerro Colorado thus suggesting formation in a back-arc basin that developed $\underline{c a}$. 125-120 Ma in the Great Antilles Arc.

The paper by Farré-de-Pablo et al. describes the singular occurrence of platinum group mineral-rich ophiolitic chromitites associated with orthopyroxenites within mantle peridotites in Havana-Matanzas, Cuba. The authors conclude that both chromitites and orthopyroxenites formed from melts with boninitic affinity in a fore-arc position during subduction beneath an intra-oceanic arc. In addition, the authors advance a hypothesis to explain the relatively high abundance of platinum group mineral inclusions in the studied chromitite.

\section{Porphyry-skarn-epithermal (porphyry Cu-Au deposits, epithermal Au-Ag, Au-Cu deposits, and Zn-Pb skarn deposits) and iron oxide copper-gold mineral systems}

The paper by Perelló et al. presents new Re-Os dates on molybdenite from the Cerro Quema gold-copper deposit in Panama fixing its age as Early Maastrichtian. In addition, the authors present mineralogical evidence from hydrothermal alteration and mineralization assemblages for a potential porphyry deposit at depth.

The paper by Nelson et al. revisits the stratigraphic and tectonic relationships between Albian Hatillo limestone and surrounding units in central Dominican Republic and its role in the controversial origin of the world-class Pueblo Viejo $\mathrm{Au}-\mathrm{Ag}-\mathrm{Cu}$ deposit.

The paper by Jiménez-Franco et al. deals with ore-forming processes in the Velardeña $\mathrm{Zn}-(\mathrm{Pb}-\mathrm{Cu})$ district in central-northern Mexico. The authors contextualize the different stages of mineralization within a telescoped skarn-epithermal mineral system.

One of the papers by Fuentes-Guzmán et al. describes the petrogenesis of the Tatatila ironoxide copper-gold (IOCG) skarn deposit provides new U-Pb (zircon) and ${ }^{40} \mathrm{Ar} /{ }^{39} \mathrm{Ar}$ ages documenting four periods of magmatic activity. This paper links the skarn mineralization at Tatatila to the regional Miocene magmatism.

Another paper by Fuentes-Guzmán et al. provides preliminary dating of the Xoconostle high sulfidation epithermal deposit, which was coeval with eruptive units in the Amealco caldera, and corroborate the metallogenic potential of Miocene-Pliocene acid bimodal magmatism along the Trans-Mexican Volcanic Belt. 
The paper by Camprubí et al. presents new ${ }^{40} \mathrm{Ar} /{ }^{39} \mathrm{Ar}$ ages for an advanced argillic assemblage in a steam-heated environment from a low-sulfidation epithermal deposit in the Ixtacamaxtitlán area. Their characterization of steam-heated alteration includes a description of rare fossil fungi in an epithermal system.

The latter three papers stand collectively as indicators of the metallogenic potential of the underexplored Trans-Mexican Volcanic Belt.

\section{Surficial mineral systems (lateritic $\mathrm{Ni}$-Co deposits, platinum placer deposits)}

The paper by Domènech et al. offers detailed descriptions of the mineralogy and chemical composition of lateritic horizons along a complete profile across the venezuelan Loma de Hierro Ni-laterite open pit, with special focus on $\mathrm{Ni}$ and Co bearing phases. Concentration patterns for Sc and rare earth elements (REE) are also described.

The paper by Tobón et al. is a study of the distribution and concentration of platinum group elements in the Cerro Matoso and Planeta Rica nickel laterite deposits in Colombia. The authors identify and describe two types of secondary PGM enrichment with implications for eventual extraction and beneficiation.

The paper by López-Males et al. provides mineralogical data on platinum-group minerals in an alluvial placer in Río Santiago in northwestern Ecuador. The variety of platinum-group minerals present is interpreted as derived from a mafic-ultramafic Ural-Alaska type complex upstream.

\section{Industrial minerals}

The article by Chong et al. offers comprehensive descriptions of northern Chile and its industrial mineral deposits. In this richly illustrated contribution, the authors delineate geological and geomorphological aspects of the "Saline Domain" and review climatic-paleoclimatic settings and related weathering and erosion agents. Future research lines including, for example, the study of microbiota in saline environments, are proposed.

The paper by Herrmann describes argentinian mineral deposits with applications to agriculture gypsum, calcium and magnesium carbonates, potassium salts, phosphates, zeolites and borates. The author describes the geologic setting and representative examples for each deposit type.

\section{Techniques for ore discovery}

Díaz-Martínez et al. present a study of predictive digital mapping of the potential for Mississippi Valley Type fluorite deposits in northeastern Mexico by means of GIS. These authors conclude that GIS techniques can be used to predict the most favorable areas for the occurrence of fluorite deposits.

\section{Regional metallogeny and mining history}

Two review papers by Redwood constitute thorough and comprehensive renditions of the ore deposits and the mining history of Panama. The papers rely on both published and unpublished sources to provide textbook quality papers that are of particular interest to exploration geologists.

\section{Acknowledgments}

The editors wish to thank the reviewers Tawn Albinson, Antonio Arribas, Idael F. Blanco Quintero, David Buchs, Fabio Cediel, Georgios Christidis, Alejandro Cisneros, Michael Druecker, Jean-Clair Duchesne, Javier Escuder Viruete, Fernando Gervilla, Cahit Helvacı, Sebastián Jovic, Malte Junge, Hildebrando Leal Mejía, Adrián Martínez Vargas, Frank Melcher, Sisir Mondal, Camilo Montes, Constantino Mpodozis, Thomas Oberthür,José Perelló, Francesco Putzolu, Nathalie Séjalon-Delmas, Mercedes Suárez Barrios, Chris Torrey, and Qing Xiong, in addition to several reviewers who wish to remain anonymous. In addition, the technical editorial staff (leaded by Salvador Vázquez), and English scientific editing services (Tom Musselman and Torrey Nyborg) made this issue possible and are wholeheartedly acknowledged. This special issue was supported by the Spanish government research grant PID2019105625RB-C21 and the Caribbean Lithosphere Research Group (GALOR). 